\title{
Streptomyces avicenniae sp. nov., a novel actinomycete isolated from the rhizosphere of the mangrove plant Avicennia mariana
}

Correspondence
Jun Xu
xu.junn@gmail.com

\author{
Jing Xiao, ${ }^{1}$ Yin Wang, ${ }^{1}$ Yingxue Luo, ${ }^{1}$ Shu-Jie Xie, ${ }^{1}$ Ji-Sheng Ruan ${ }^{1}$ \\ and Jun $X u^{1,2}$ \\ ${ }^{1}$ Key Laboratory of Marine Biogenetic Resources, The Third Institute of Oceanography SOA, \\ Xiamen, Fujian, 361005, PR China
${ }^{2}$ School of Life Sciences \& Biotechnology, Shanghai Jiao Tong University, Shanghai, 200240, PR China

\begin{abstract}
A novel isolate, designated strain MCCC $1 \mathrm{~A} 01535^{\top}$, belonging to the genus Streptomyces was isolated from the rhizosphere of the mangrove plant Avicennia mariana from Fujian Province, south China. Characterization of the isolate was based on a polyphasic approach. Pairwise comparison of $16 \mathrm{~S}$ rRNA gene sequences revealed that strain MCCC $1 \mathrm{~A} 01535^{\top}$ shared 97.7 and $97.5 \%$ sequence similarities to Streptomyces specialis GW41-1564 ${ }^{\top}$ and Streptomyces hainanensis YIM47672 ${ }^{\top}$, respectively, its most closely related neighbours, whereas the DNADNA relatedness value between strains MCCC $1 \mathrm{~A} 01535^{\top}$ and $\mathrm{GW} 41-1564^{\top}$ was $50.2 \%$. The major fatty acids of strain MCCC $1 A 01535^{\top}$ were iso- $C_{16: 0}, C_{16: 0}$ and anteiso- $C_{15: 0}$. These differed from the fatty acid compositions of related strains. Strain MCCC $1 \mathrm{~A} 01535^{\top}$ exhibited an unusual menaquinone system that comprised $\mathrm{MK}-10\left(\mathrm{H}_{6}\right)$ as the predominant component and moderate amounts of MK- $9\left(\mathrm{H}_{6}\right)$, MK- $9\left(\mathrm{H}_{8}\right)$ and MK-10 $\left(\mathrm{H}_{8}\right)$; minor amounts of MK- $9\left(\mathrm{H}_{4}\right)$, MK$10\left(\mathrm{H}_{4}\right), M K-9\left(\mathrm{H}_{10}\right)$ and MK-10 $\left(\mathrm{H}_{10}\right)$ were also present. Based on its chemotaxonomic, phenotypic and genotypic characteristics, strain MCCC $1 \mathrm{~A} 01535^{\top}$ is considered to represent a novel species of the genus Streptomyces, for which the name Streptomyces avicenniae sp. nov. is proposed. The type strain is MCCC 1 A01535 ${ }^{\top}\left(=\mathrm{DSM} 41943^{\top}=\mathrm{CGMCC}_{4.5510^{\top}}\right)$.
\end{abstract}

Members of the genus Streptomyces, proposed by Waksman \& Henrici (1943), are a rich source of novel bioactive, commercially significant compounds. Although Streptomyces strains were frequently isolated from terrestrial environments, they have also been recovered from aquatic and symbiotic environments. Marine actinomycetes have been recognized as a resource for biotechnology in recent years (Bull et al., 2000). Analysis of the diversity of actinomycetes isolated from Challenger-Deep sediment from the Mariana Trench has proven the presence of Streptomyces in the deep-sea environment (Pathom-Aree et al., 2006).

Mangrove forests are highly productive ecosystems that comprise diverse flora and fauna of marine, freshwater and terrestrial species (Jennerjahn \& Ittekkot, 2002). The exploitation of the profusion of mangrove micro-organism resources has been expanded in many aspects (Long et al.,

The GenBank/EMBL/DDBJ accession number for the 16S rRNA gene sequence of strain MCCC 1 A01535 ${ }^{\top}$ is EU399234.

Tables showing major quinone and major fatty acid compositions are available as supplementary material with the online version of this paper.
2005), including the screening of novel actinomycetes that could be a dormant source of new natural products. A systematic investigation of the actinomycete diversity in the National mangrove reserve in Fujian Province, China was performed, during which strain MCCC $1 \mathrm{~A} 01535^{\mathrm{T}}$ was isolated. Here, we report the results of a polyphasic taxonomic investigation on strain MCCC $1 \mathrm{~A} 01535^{\mathrm{T}}$ and propose that it represents the type strain of a novel species of the genus Streptomyces that exhibits an unusual menaquinone system.

Strain MCCC $1 \mathrm{~A} 01535^{\mathrm{T}}$ was isolated after 2 weeks incubation at $28{ }^{\circ} \mathrm{C}$ on ISP 2 agar (Shirling \& Gottlieb, 1966). Morphological observations of spores and mycelia on Gause's synthetic agar at $28{ }^{\circ} \mathrm{C}$ for 12 days were made by using light microscopy (COBER-015; Olympus) and scanning electron microscopy (XL30 ESEM-TMP; PhilipsFEI). Cultural characteristics were determined after 3 weeks incubation at $28{ }^{\circ} \mathrm{C}$ by using methods in the ISP (Shirling \& Gottlieb, 1966). Colours were assessed according to colour chips in the ISCC-NBS Colour Charts Standard no. 2106 (Kelly, 1964). Biomass of strain MCCC $1 \mathrm{~A} 01535^{\mathrm{T}}$ for chemical and molecular analyses was grown in ISP 2 liquid 
Table 1. Cultural characteristics of strain MCCC $1 \mathrm{~A} 01535^{\top}$ on various media at $28^{\circ} \mathrm{C}$ after 7 days

- , Not detected.

\begin{tabular}{|lcccc|}
\hline Medium & Growth & Soluble pigment & & \multicolumn{2}{c|}{ Colony colour } \\
\cline { 3 - 5 } & & & Aerial mycelium & Substrate mycelium \\
\hline Yeast extract agar (ISP 2) & Moderate & Deep-brown & Deep orange-red & Deep orange-red \\
Oatmeal agar (ISP 3) & Good & - & Yellow-brown & Yellow-brown \\
Inorganic salts-starch agar (ISP 4) & Good & - & Olive & Grey \\
Glycerol-asparagine agar (ISP 5) & Moderate & - & Olive & Grey \\
Czapek's agar & Poor & - & Light yellow & White \\
Starch agar & Good & - & Yellow-brown & Yellow-brown \\
Glucose-asparagine agar & Good & - & & \\
\end{tabular}

broth for $3-5$ days at $28{ }^{\circ} \mathrm{C}$ in a rotary shaker (180 r.p.m.) and harvested by centrifugation.

The isolate grew well on ISP 3 and 4 agar media with moderate growth occurring on other media. The colours of the aerial and substrate mycelium were media-dependent (Table 1). A deep-brown soluble pigment was produced on ISP 2 media. At maturity, the aerial mycelium developed well on Gause's synthetic agar. The spore chains were compact spiral and contained about eight helixes per chain. The spores were elliptical and non-motile with smooth surfaces (Fig. 1).

The temperature range for growth was determined on modified ISP 2 agar at 4, 10, 15, 20, 28, 37 and $45{ }^{\circ} \mathrm{C}$ for 1 to 2 weeks. Carbohydrate utilization was carried out according to the method of Kämpfer et al. (1991). Gelatin liquefaction, starch hydrolysis, milk coagulation and peptonization, melanin pigment production, nitrate reduction and $\mathrm{H}_{2} \mathrm{~S}$ production were tested using the methods of Goodfellow (1971) and Gordon et al. (1974). Resistance to various antibiotics was determined with antimicrobial susceptibility discs (Oxoid). Phenotypic characteristics that differentiate strain MCCC $1 \mathrm{~A} 01535^{\mathrm{T}}$ from related Streptomyces species are given in Table 2.

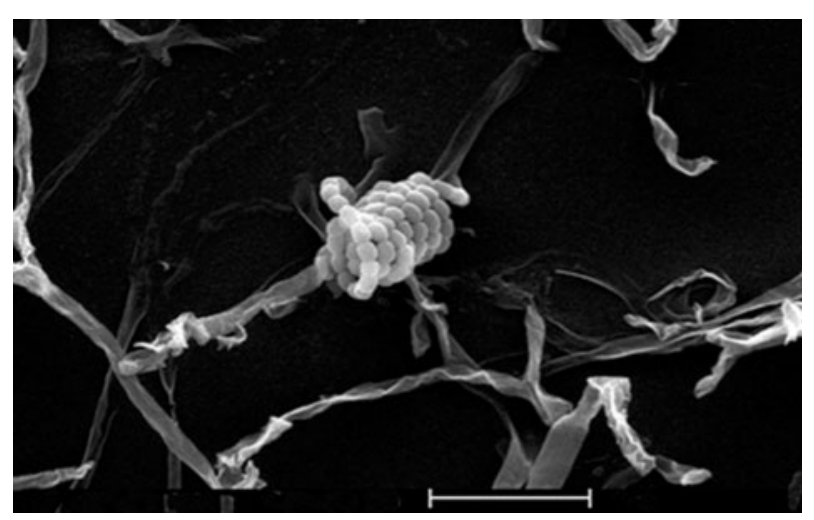

Fig. 1. Scanning electron micrograph of spore chains of strain MCCC $1 \mathrm{~A} 01535^{\top}$ grown on Gause's synthetic agar for 10 days at $28^{\circ} \mathrm{C}$. Bar, $5 \mu \mathrm{m}$.
Analyses of the diagnostic isomer of the diaminopimelic acid $\left(\mathrm{A}_{2} \mathrm{pm}\right)$ and whole-cell sugars were done using freezedried cells that were hydrolysed with 6 and $0.5 \mathrm{M} \mathrm{HCl}$ at $120{ }^{\circ} \mathrm{C}$ for $30 \mathrm{~min}$ (Lechevalier \& Lechevalier, 1980), and analysed by TLC (Hasegawa et al., 1983). Phospholipid analysis was carried out as described by Komagata \& Suzuki (1987). The cellular fatty acid composition was determined as described by Sasser (1990) using the Microbial Identification System (MIDI, Inc.) and Sherlock MIS Software.

Amino acids in the peptidoglycan layer of strain MCCC $1 \mathrm{~A} 01535^{\mathrm{T}}$ were $\mathrm{LL}-\mathrm{A}_{2} \mathrm{pm}$, alanine, glycine and glutamic acid. Whole-cell hydrolysates contained ribose, xylose, arabinose, galactose and glucose. Diphosphatidylglycerol

Table 2. Phenotypic characteristics that differentiate strain MCCC $1 \mathrm{~A} 1535^{\mathrm{T}}$ from related Streptomyces species

Strains: 1, MCCC $1 \mathrm{~A} 01535^{\mathrm{T}}$ (S. avicenniae sp. nov.); 2, S. specialis GW41-1564 ${ }^{\mathrm{T}} ; 3$, S. hainanensis YIM $47672^{\mathrm{T}}$. Data for S. specialis and S. hainanensis were from Kämpfer et al. (2008) and Jiang et al. (2007). All strains do not utilize D-mannose. +, Positive; -, negative; ND, not determined.

\begin{tabular}{|c|c|c|c|}
\hline Characteristic & 1 & 2 & 3 \\
\hline \multicolumn{4}{|c|}{ Production of diffusible pigment } \\
\hline On ISP 3 and ISP 4 & - & + & + \\
\hline On ISP 5 & - & + & - \\
\hline $\mathrm{H}_{2} \mathrm{~S}$ production & - & - & + \\
\hline Nitrate reduction & - & - & + \\
\hline Gelatin liquefaction & + & + & - \\
\hline Milk coagulation & + & + & - \\
\hline Milk peptonization & + & + & - \\
\hline \multicolumn{4}{|l|}{ Utilization of: } \\
\hline D-Xylose & + & - & ND \\
\hline D-Galactose & + & - & - \\
\hline Inositol & - & + & - \\
\hline L-Arabinose & + & - & - \\
\hline D-Ribose & - & + & - \\
\hline L-Rhamnose & + & - & - \\
\hline Sucrose & + & + & - \\
\hline
\end{tabular}


was the predominant polar lipid. Phosphatidylethanolamine, phosphatidylcholine, phosphatidylinositol and an unknown phospholipid were present in minor amounts. The major cellular fatty acids were iso- $\mathrm{C}_{16: 0}(32.0 \%)$, $\mathrm{C}_{16: 0}(15.1 \%)$ and anteiso- $\mathrm{C}_{15: 0}(10.7 \%)$.

Menaquinones were extracted by using the method of Collins et al. (1977) and analysed by HPLC (Kroppenstedt, 1985). The quinone system of strain MCCC $1 \mathrm{~A} 01535^{\mathrm{T}}$ consisted of the predominant menaquinone MK-10 $\left(\mathrm{H}_{6}\right)$ $(29 \%)$ and moderate amounts of MK-9 $\left(\mathrm{H}_{6}\right)(16.8 \%)$, MK-9 $\left(\mathrm{H}_{8}\right) \quad(16.3 \%)$ and MK-10 $\left(\mathrm{H}_{8}\right) \quad(14.8 \%)$. Minor amounts $(<10 \%)$ of MK-9 $\left(\mathrm{H}_{4}\right) \quad(6.7 \%)$, MK-10 $\left(\mathrm{H}_{4}\right)$ $(9.4 \%)$, MK-9 $\left(\mathrm{H}_{10}\right)(3.0 \%)$ and MK-10( $\left.\mathrm{H}_{10}\right)(4.0 \%)$ were also present.

Genomic DNA was extracted as described by Weisburg et al. (1991). DNA was digested and dephosphorylated prior to the determination of the base composition by using HPLC (Tamaoka \& Komagata, 1984). The G+C content of the DNA was calculated according to Mesbah et al. (1989). The $\mathrm{G}+\mathrm{C}$ content of the DNA strain MCCC $1 \mathrm{~A} 01535^{\mathrm{T}}$ was determined to be $73.3 \mathrm{~mol} \%$.

Amplification of the 16S rRNA gene sequence was performed as described by Cui et al. (2001). An almostcomplete 16S rRNA gene sequence (1491 nt) of strain MCCC $1 \mathrm{~A} 01535^{\mathrm{T}}$ was obtained and compared against the GenBank and EzTaxon databases using BLAST (Altschul et al., 1997; Chun et al., 2007). The 16S rRNA gene sequences of representative related actinomycetes were aligned using CLUSTAL_X (Thompson et al., 1997) and a phylogenetic tree was constructed by using maximumparsimony and neighbour-joining with MEGA 3.1 software (Kumar et al., 2004; Saitou \& Nei, 1987). The topology of the tree was evaluated by using a bootstrap analysis (Felsenstein, 1985) with 1000 replications. Strain MCCC $1 \mathrm{~A} 01535^{\mathrm{T}}$ formed a distinct branch with Streptomyces specialis GW41-1564 ${ }^{\mathrm{T}}$ in the phylogenetic tree (Fig. 2). The highest $16 \mathrm{~S}$ rRNA sequence similarities between the isolate and type strains of recognized species in the databases were $97.7 \%$ to S. specialis GW41-1564 ${ }^{\mathrm{T}}$ (Kämpfer et al., 2008) and $97.5 \%$ to Streptomyces hainanensis YIM $47672^{\mathrm{T}}$ (Jiang et al., 2007).
DNA-DNA relatedness studies were carried out between strain MCCC $1 \mathrm{~A} 01535^{\mathrm{T}}$ and the closely related strain GW41-1564 ${ }^{\mathrm{T}}$ using DIG-High prime DNA labelling and detection starter kit II (Roche), as described in the instruction manual. Chromosomal DNA of the strains was digested by HaeIII. Fragments of $400 \mathrm{bp}$ to $5 \mathrm{~kb}$ were collected and labelled as a probe. The total chromosomal DNA was spotted onto Hybond-N + nylon membrane (Amersham) for hybridization. DNA-DNA relatedness values were $50.2 \%$, below the recommended criterion of $80 \%$ for species delineation of the genus Streptomyces (Labeda, 1992).

According to Kim et al. (2003), the major menaquinones of the genus Streptomyces are MK- $9\left(\mathrm{H}_{6}\right)$ and MK- $9\left(\mathrm{H}_{8}\right)$. It was interesting that strains GW41-1564 ${ }^{\mathrm{T}}$ and YIM $47672^{\mathrm{T}}$ both contained unusual quinone systems, but strain MCCC $1 \mathrm{~A} 01535^{\mathrm{T}}$ exhibited a distinct quinone system that was different from both of them (see Supplementary Table S1, available in IJSEM Online). The detailed profile of the cellular fatty acids given in Supplementary Table S2 (in IJSEM Online) and the sugar pattern gave additional support for the separation of strain MCCC $1 \mathrm{~A} 01535^{\mathrm{T}}$ from the related strains GW41-1564 ${ }^{\mathrm{T}}$ and YIM $47672^{\mathrm{T}}$.

Strain MCCC $1 \mathrm{~A} 01535^{\mathrm{T}}$ showed a notable difference in the production of diffusible pigment from its closest relatives. The three strains could be discriminated based on the predominant menaquinones. Based on morphology, chemotaxonomy and $16 \mathrm{~S}$ rRNA phylogeny, it can be concluded that strain MCCC $1 \mathrm{~A} 01535^{\mathrm{T}}$ represents a novel species of the genus Streptomyces, for which we propose the name Streptomyces avicenniae sp. nov.

\section{Description of Streptomyces avicenniae sp. nov.}

Streptomyces avicenniae (a.vi.cen'ni.ae. N.L. fem. n. Avicennia scientific name of genus of tree; N.L. fem. gen. n. avicenniae of Avicennia, isolated from the rhizosphere of the plant Avicennia mariana).

Aerobic, Gram-positive actinomycete with branching aerial mycelium and substrate mycelium. Non-motile and ellipsoid spores with smooth surfaces are borne in compact spiral spore chains with up to eight helixes per chain.

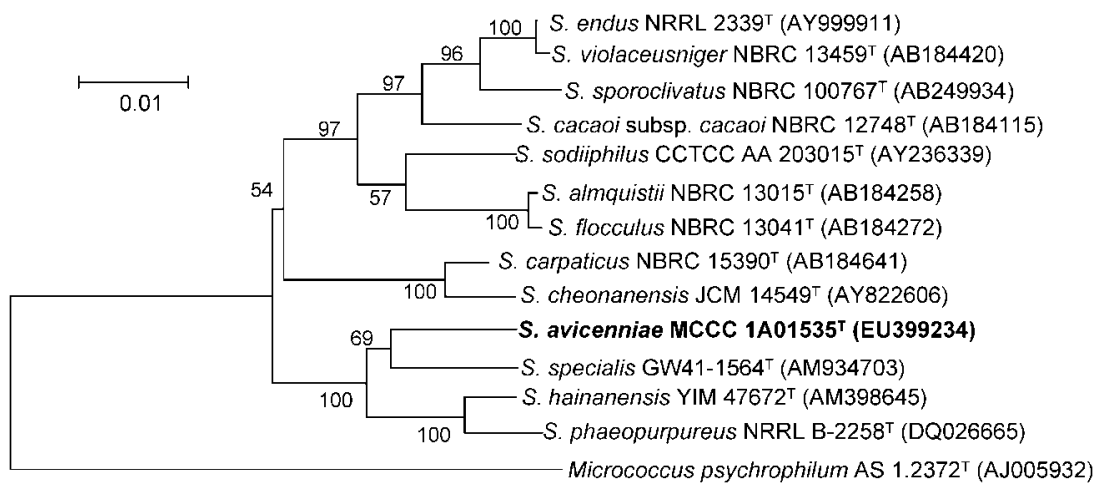

Fig. 2. Phylogenetic dendrogram obtained by using neighbour-joining analysis based on $16 \mathrm{~S}$ rRNA gene sequences (1458 bp, by omitting unaligned regions), showing the positions of strain MCCC $1 \mathrm{~A} 01535^{\top}$ and related strains. The sequence of the type strain of Micrococcus psychrophilum was used as an outgroup. Only bootstrap values above $50 \%$, expressed as percentages of 1000 replications, are shown at branch points. Bar, 0.01 substitutions per nucleotide position. 
Colony colour is medium-dependent and diffusible pigments are produced on ISP 2 media. Aerial mycelia are light-yellow on Czapek's agar and Starch agar, yellowbrown on glucose-asparagine agar and ISP 3, olive on ISP 4 and ISP 5 , and deep orange-red on ISP 2. Substrate mycelia are white, grey to light-yellow and deep orange-red on different media. Growth occurs at temperatures ranging from 15 to $37{ }^{\circ} \mathrm{C}$, with optimum growth at $28{ }^{\circ} \mathrm{C}$. Raffinose, D-xylose, D-galactose, L-arabinose, L-rhamnose, mannitol and sucrose are utilized, but D-mannose, inositol and Dribose are not. Tests for gelatin liquefaction, milk coagulation and peptonization are positive and tests for nitrate reduction, $\mathrm{H}_{2} \mathrm{~S}$ production and melanin production are negative. Cell wall contains LL-diaminopimelic acid. Wholecell hydrolysates contain ribose, xylose, arabinose, galactose and glucose. Resistant to ciprofloxacin $(5 \mu \mathrm{g})$, clindamycin $(2 \mu \mathrm{g})$, furazolidone $(15 \mu \mathrm{g})$, metronidazole $(5 \mu \mathrm{g})$, lincomycin $(2 \mu \mathrm{g})$ and norfloxacin $(10 \mu \mathrm{g})$. Sensitive to ampicillin $(10 \mu \mathrm{g})$, chloromycetin $(30 \mu \mathrm{g})$, rocephin $(30 \mu \mathrm{g})$, erythromycin $(15 \mu \mathrm{g})$, kanamycin $(30 \mu \mathrm{g})$, cefazolin $(30 \mu \mathrm{g})$, neomycin $(10 \mu \mathrm{g})$, penicillin $\mathrm{G}(10 \mu \mathrm{g})$, rifampicin $(5 \mu \mathrm{g})$ and vancomycin $(30 \mu \mathrm{g})$. Major menaquinone is MK-10 $\left(\mathrm{H}_{6}\right)$ with moderate amounts of MK-9 $\left(\mathrm{H}_{6}\right)$, MK9( $\left.\mathrm{H}_{8}\right)$, MK-10 $\left(\mathrm{H}_{8}\right)$, MK-9 $\left(\mathrm{H}_{4}\right)$, MK-10 $\left(\mathrm{H}_{4}\right)$, MK-9 $\left(\mathrm{H}_{10}\right)$ and MK-10 $\left(\mathrm{H}_{10}\right)$. Diagnostic phospholipids are diphosphatidylglycerol with minor amounts of phosphatidylethanolamine, phosphatidylcholine and phosphatidylinositol and an unknown phospholipid. Major fatty acid components are iso- $\mathrm{C}_{16: 0}, \mathrm{C}_{16: 0}$ and anteiso- $\mathrm{C}_{15: 0}$. The $\mathrm{G}+\mathrm{C}$ content of the DNA of the type strain is $73.3 \mathrm{~mol} \%$.

The type strain, MCCC $1 \mathrm{~A} 01535^{\mathrm{T}}\left(=\mathrm{DSM} 41943^{\mathrm{T}}=\right.$ CGMCC $4.5510^{\mathrm{T}}$ ), was isolated from the rhizosphere of the mangrove plant Avicennia mariana from Fujian Province, south China.

\section{Acknowledgements}

J.X. is indebted to the National Science Foundation of China (40606031), the National High Technology R\&D Program of China (2006AA09Z437), the National Basic Research Program of China (2006CB708200) and the National Infrastructure Program of Natural Resources of S\&T of China (2005DKA21209). J.X. gratefully acknowledges Professor Wen-Jun $\mathrm{Li}$ for technical supervision of some chemotaxonomic analyses in the Yunnan Institute of Microbiology.

\section{References}

Altschul, S. F., Madden, T. L., Schaffer, A. A., Zhang, J., Zhang, Z., Miller, W. \& Lipman, D. J. (1997). Gapped BLAST and PSI-BLAST: a new generation of protein database search programs. Nucleic Acids Res 25, 3389-3402.

Bull, A. T., Ward, A. C. \& Goodfellow, M. (2000). Search and discovery strategies for biotechnology: the paradigm shift. Microbiol Mol Biol Rev 64, 573-606.

Chun, J., Lee, J. H., Jung, Y., Kim, M., Kim, S., Kim, B. K. \& Lim, Y. W. (2007). EzTaxon: a web-based tool for the identification of prokaryotes based on $16 \mathrm{~S}$ ribosomal RNA gene sequences. Int J Syst Evol Microbiol 57, 2259-2261.
Collins, M. D., Pirouz, T., Goodfellow, M. \& Minnikin, D. E. (1977). Distribution of menaquinones in actinomycetes and corynebacteria. J Gen Microbiol 100, 221-230.

Cui, X. L., Mao, P. H., Zeng, M., Li, W. J., Zhang, L. P., Xu, L. H. \& Jiang, C. L. (2001). Streptimonospora salina gen. nov., sp. nov., a new member of the family Nocardiopsaceae. Int J Syst Evol Microbiol 51, 357-363.

Felsenstein, J. (1985). Confidence limits on phylogenies: an approach using the bootstrap. Evolution 39, 783-791.

Goodfellow, M. (1971). Numerical taxonomy of some nocardioform bacteria. J Gen Microbiol 69, 33-80.

Gordon, R. E., Barnett, D. A., Handerhan, J. E. \& Pang, C. H.-N. (1974). Nocardia coeliaca, Nocardia autotrophica, and the nocardin strain. Int J Syst Bacteriol 24, 54-63.

Hasegawa, T., Takizawa, M. \& Tanida, S. (1983). A rapid analysis for chemical grouping of aerobic actinomycetes. J Gen Appl Microbiol 29, 319-322.

Jennerjahn, T. C. \& Ittekkot, V. (2002). Relevance of mangroves for the production and deposition of organic matter along tropical continental margins. Naturwissenschaften 89, 23-30.

Jiang, Y., Tang, S. K., Wiese, J., Xu, L. H., Imhoff, J. F. \& Jiang, C. L. (2007). Streptomyces hainanensis sp. nov., a novel member of the genus Streptomyces. Int J Syst Evol Microbiol 57, 2694-2698.

Kämpfer, P., Kroppenstedt, R. M. \& Dott, W. (1991). A numerical classification of the genera Streptomyces and Streptoverticillium using miniaturized physiological tests. J Gen Microbiol 137, 1831-1891.

Kämpfer, P., Huber, B., Buczolits, S., Thummes, K., Grun-Wollny, I. \& Busse, H.-J. (2008). Streptomyces specialis sp. nov. Int J Syst Evol Microbiol 58, 2602-2606.

Kelly, K. L. (1964). Color-name Charts Illustrated with Centroid Colors. Chicago: Inter-Society Color Council-National Bureau of Standards.

Kim, S. B., Lonsdale, J., Seong, C. N. \& Goodfellow, M. (2003). Streptacidiphilus gen. nov., acidophilic actinomycetes with wall chemotype I and emendation of the family Streptomycetaceae (Waksman and Henrici $1943^{\mathrm{AL}}$ ) emend. Rainey et al. 1997. Antonie Van Leeuwenhoek 83, 107-116.

Komagata, K. \& Suzuki, K. (1987). Lipid and cell-wall analysis in bacterial systematics. Methods Microbiol 19, 161-207.

Kroppenstedt, R. M. (1985). Fatty acid and menaquinone analysis of actinomycetes and related organisms. In Chemical Methods in Bacterial Systematics (Society for Applied Bacteriology Technical Series vol. 20), pp. 173-199. Edited by M. Goodfellow \& D. E. Minnikin. New York: Academic Press.

Kumar, S., Tamura, K. \& Nei, M. (2004). MEGA3: integrated software for Molecular Evolutionary Genetics Analysis and sequence alignment. Brief Bioinform 5, 150-163.

Labeda, D. P. (1992). DNA-DNA hybridization in the systematics of Streptomyces. Gene 115, 249-253.

Lechevalier, M. P. \& Lechevalier, H. A. (1980). The chemotaxonomy of actinomycetes. In Actinomycete Taxonomy, pp. 227-291. Edited by A. Dietz \& D. W. Thayer. Arlington, VA: Society for Industrial Microbiology.

Long, H., Xiang, W., Zhuang, T. \& Lin, P. (2005). Microorganism resource of mangrove ecosystems. Chinese Journal of Ecology 24, 696-702.

Mesbah, M., Premachandran, U. \& Whitman, W. B. (1989). Precise measurement of the $\mathrm{G}+\mathrm{C}$ content of deoxyribonucleic acid by highperformance liquid chromatography. Int J Syst Bacteriol 39, 159-167.

Pathom-Aree, W., Stach, J. E., Ward, A. C., Horikoshi, K., Bull, A. T. \& Goodfellow, M. (2006). Diversity of actinomycetes isolated from Challenger Deep sediment $(10,898 \mathrm{~m})$ from the Mariana Trench. Extremophiles 10, 181-189. 
Saitou, N. \& Nei, M. (1987). The neighbor-joining method: a new method for reconstructing phylogenetic trees. Mol Biol Evol 4, 406-425.

Sasser, M. (1990). Identification of bacteria by gas chromatography of cellular fatty acids. USFCC Newsl 20, 16.

Shirling, E. B. \& Gottlieb, D. (1966). Methods for characterization of Streptomyces species. Int J Syst Bacteriol 16, 313-340.

Tamaoka, J. \& Komagata, K. (1984). Determination of DNA base composition by reversed-phase high-performance liquid chromatography. FEMS Microbiol Lett 25, 125-128.
Thompson, J. D., Gibson, T. J., Plewniak, F., Jeanmougin, F. \& Higgins, D. G. (1997). The CLUSTAL_X windows interface: flexible strategies for multiple sequence alignment aided by quality analysis tools. Nucleic Acids Res 25, 4876-4882.

Waksman, S. A. \& Henrici, A. T. (1943). The nomenclature and classification of the actinomycetes. J Bacteriol 46, 337-341.

Weisburg, W. G., Barns, S. M., Pelletier, D. A. \& Lane, D. J. (1991). $16 \mathrm{~S}$ ribosomal DNA amplification for phylogenetic study. J Bacteriol 173, 697-703. 